\title{
The Direct Conversion of Synthesis Gas into Ethylene Glycol Catalyzed by Rhodium
}

\author{
Yuji OHGOMORI \\ Central Research Laboratory, Mitsubishi Petrochemical Co., Ltd., \\ 8-3-1 Chu-ou, Ami, Ibaraki 300-03
}

(Received November 2, 1987)

\begin{abstract}
Recent advances in the direct conversion of synthesis gas to form ethylene glycol catalyzed by rhodium are summarized. High-rate conversions of synthesis gas are achieved in alkyl-substituted pyrrolidones or urea derivatives used as solvents. The formation of glycol is greatly facilitated by phosphine-promoted rhodium catalysts. The catalytic activity is determined by the electronic and steric effects of the phosphine. The rate of ethylene glycol formation increases with increasing electron-donating properties of the phosphine. The steric hindrance of the ligand inhibits electronic effects on glycol formation. Carboxylic acids (HX) facilitate the formation of ethylene glycol catalyzed by the Rh/phosphine (L) system. Recovered complexes from the resultant solutions were identified as $\mathrm{RhX}(\mathrm{CO}) \mathrm{L}_{2}$, which are stable under repeated usage. The acids play an important role in the catalytic activity and stability of the rhodium complexes.
\end{abstract}

\section{Introduction}

The importance of synthesis gas $\left(\mathrm{CO} / \mathrm{H}_{2}\right.$ mixture) as a raw material for production of commodity chemicals has been recognized since world crude oil, accordingly naphtha, is predicted to be exhausted in the foreseeable future. Among the possible products from synthesis gas, ethylene glycol (EG) is most preferred because of its oxygenated structure that favors a greater product/raw-material ratio by weight. The direct conversion of synthesis gas into EG has thus been an interesting target for research in recent years. ${ }^{1)}$ Cobalt $^{2 \text { ) }}$, ruthenium ${ }^{3)}$, and rhodium $^{4)}$ have been known to form effective catalysts. Early studies on cobalt catalysts have been restricted by use of very high pressures. The direct conversion of synthesis gas by ruthenium catalysts has been known to be effective compared to that by cobalt catalysts. However, the selectivity to EG of ruthenium catalysts was generally lower than that of rhodium catalysts.

The rhodium-alkali salt and/or tertiary amine system has been proposed to form active and selective catalysts. The recovered complex has been identified as an unstable rhodium cluster compound such as $\left[\mathrm{Rh}_{12}(\mathrm{CO})_{30}\right]^{2-}$ or $\left[\mathrm{Rh}_{13}-\right.$ $\left.(\mathrm{CO})_{32}\right]^{2-}$.1) The catalyst must be recovered in a more stable form for practical applications. Recent investigations show that Rh-phosphine (L) system yields novel catalysts in which mononuclear rhodium species such as $\mathrm{HRh}(\mathrm{CO})$ $\mathrm{L}_{3}{ }^{5}$ ) or $\mathrm{HRh}(\mathrm{CO})_{3} \mathrm{~L}^{6), 7)}$ have been recognized as plausible catalytically active species. The catalytic activity is greatly enhanced in the presence of a tertiary amine. ${ }^{8)}$ Complex $\left[\mathrm{Rh}(\mathrm{CO})_{3} \mathrm{~L}\right]_{2}$ is recovered.9) The rhodium complex is known to be stable under carbon monoxide atmosphere ${ }^{9)}$, but it may decompose under nitrogen atmosphere.

In this paper, recent advances in the catalytic activity and stability of rhodium catalysts for synthesis of EG are described.

\section{Results and Discussion}

\subsection{Unpromoted Rhodium Catalysts}

It is already known that rhodium catalyzes the formation of EG in 1-methylpyrrolidin-2-one (NMP) at the pressure of 2,000 bar, but its selectivity is very low.4) We have found that its catalytic activity and selectivity to EG are greatly enhanced by the use of 1-alkylpyrrolidin-2-one in which the alkyl substituent is more electron donative than the methyl. ${ }^{10}$ ) Rhodium effectively catalyzes the reaction also in urea solvents such as 1,3-dimethylimidazolidin-2-one (DMI) and 1,1, 3,3-tetramethylurea (TMU). ${ }^{11)}$ The results are summarized in Table 1, together with the comparative results obtained in NMR solvent. Linear relationships are found between rates of EG or methanol (MeOH) conversion and Taft's substitution constants of the alkyl substituent in pyrrolidin-2-one with correlation coefficients of -0.945 and 0.947 , respectively.

IR studies of the reaction solutions have shown that rhodium exists mainly as a cluster anion $\left.\mathrm{Rh}_{6}(\mathrm{CO})_{15^{2-}}\left(2,040,1,985 \text {, and } 1,960 \mathrm{~cm}^{-1}\right)^{12}\right)$ in 
Table 1 Hydrogenation of CO in Pyrrolidin-2-ones or Urea Derivatives ${ }^{\text {a) }}$

\begin{tabular}{|c|c|c|}
\hline Solvent & \multicolumn{2}{|c|}{$\begin{array}{l}\left.\text { Turnover number }\left(\mathrm{hr}^{-1}\right)^{\mathrm{b}}\right) \\
\mathrm{MeO}\end{array}$} \\
\hline $\begin{array}{l}\text { 1-Methylpyrrolidin-2-one (NMP) } \\
\text { 1-Ethylpyrrolidin-2-one } \\
\text { 1-Butylpyrrolidin-2-one } \\
\text { 1-Isopropylpyrrolidin-2-one } \\
\text { 1,3-Dimethylimidazolidin-2-one (DMI) } \\
\text { 1,1,3,3-Tetramethylurea (TMU) }\end{array}$ & $\begin{array}{l}0.72 \\
0.91 \\
1.16 \\
1.88 \\
1.85 \\
1.41\end{array}$ & $\begin{array}{l}2.55 \\
2.20 \\
2.02 \\
1.52 \\
1.41 \\
0.66\end{array}$ \\
\hline
\end{tabular}

a) $[\mathrm{Rh}]=0.04 \mathrm{M}\left[\mathrm{Rh}_{4}(\mathrm{CO})_{12}\right.$ was used]; solvent, $20 \mathrm{ml}$;

$\mathrm{CO} / \mathrm{H}_{2}(1 / 1), 403-390 \mathrm{bar} ; 200^{\circ} \mathrm{C} ; 4 \mathrm{hr}$.

b) Turnover numbers for ethylene glycol (EG) and methanol $(\mathrm{MeOH})$.

Table 2 Identified Products in DMI or NMP ${ }^{\mathrm{a})}$

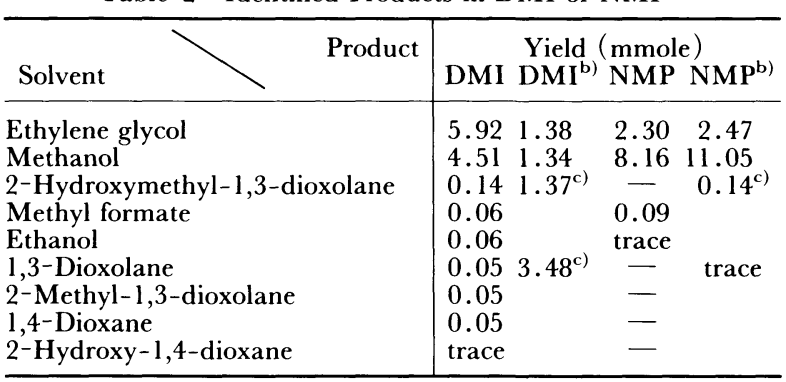

a) Reaction conditions as in Table 1 .

b) $50 \mathrm{ml}$ of 1,2-propylene glycol was employed.

c) 4-Methyl-substituted derivative.

amide or urea solvents except for NMP, which yields mononuclear species $\mathrm{Rh}(\mathrm{CO})_{4}{ }^{-}(1,900$ $\left.\mathrm{cm}^{-1}\right)$. This seems to indicate that the plausible catalytically active species in the solvent systems are $\mathrm{H}_{2} \mathrm{Rh}_{6}(\mathrm{CO})_{15}(\mathbf{1})$ and $\mathrm{HRh}(\mathrm{CO})_{4}(2)$, respectively.

In the next step, by-products in the reaction solution were analyzed. The intermediates in the synthesis of EG from synthesis gas have been assumed to be $\mathrm{HCHO}$ and $\mathrm{HOCH}_{2} \mathrm{CHO}$, since trace quantities of 1,3-dioxolane and 2-hydroxymethyl-1,3-dioxolane have been detected. ${ }^{13)}$ These by-products are detected in the reaction solution of DMI. However, no dioxolanes are found in NMP as shown in Table 2. The formation of dioxolanes in DMI solvent is facilitated by the presence of 1,2-diol, e.g., 1,2-propylene glycol, but yields of dioxolanes in NMP are very low (Table 2). This may suggest that the intermediates such as $\mathrm{HCHO}$ and $\mathrm{HOCH}_{2} \mathrm{CHO}$ exist in larger quantities in DMI than in NMP solvent. A reaction pathway in the basic solvent is proposed in Scheme 1. The ion-paired formyl species 3 has been isolated for iron complexes. ${ }^{14)}$ In the case of rhodium catalysts using amide solvents, the formation of the formaldehyde intermediate would be accelerated through the formation of $\mathbf{3}$ stabilized by the $[\text { Solv } \cdot \mathrm{H}]^{15)}$ cation. Species 4 or 5 is formed by adding HCHO to 1 or 2 . As to the formation ratios of $\mathbf{4}$ and $\mathbf{5}$, the presence of basic

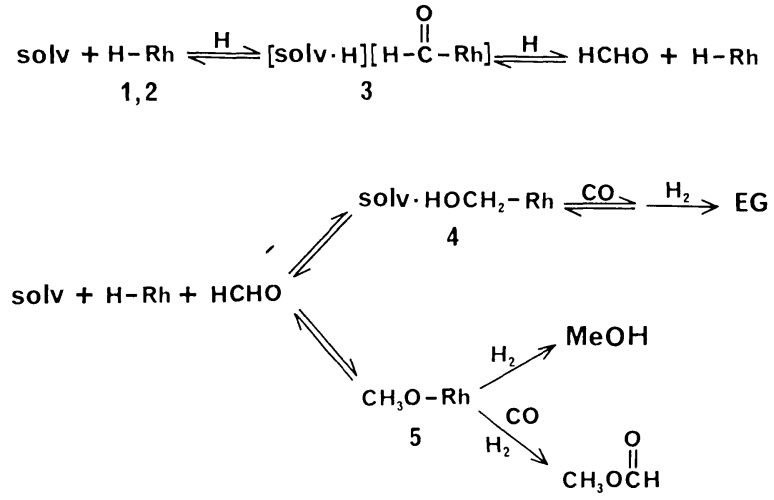

Scheme 1 Proposed Reaction Pathway in Amide or Urea Solvent

solvent will favor 4, resulting in the improved selectivity to EG in DMI solvent. On the other hand, NMP accelerates the conversion of $\mathbf{5}$ into $\mathrm{MeOH}$ as shown in Table $\mathbf{1}$, and the conversion of 5 reduces the concentration of the formaldehyde intermediate, leading to the preferential formation of 5 over 4 . This may be the cause of the lower selectivity to EG in NMP solvent.

\subsection{Phosphine-promoted Rhodium Catalysts}

The Rh-triarylphosphine, e.g., triphenylphosphine, system is known to be an excellent catalyst for hydroformylation of olefins. ${ }^{16)}$ It is known that trialkylphosphines promote the synthesis of EG from synthesis gas catalyzed by rhodium, although triarylphosphines inhibit the hydrogenation of carbon monoxide. ${ }^{6)}$,7) The catalytic activity is thought to be dependent on the electronic/steric effect ${ }^{6}$ ) or the steric effect ${ }^{7)}$ of the phosphine ligand, but it has not been clearly demonstrated which effect is the more important to govern the catalytic activity.

We have investigated the promoting effect of tertiary phosphine of the types $\operatorname{Pr}_{2} \mathrm{PR}$ and $\left(\mathrm{CH}_{2}\right)_{5} \mathrm{PR}$ ( $\mathrm{R}=$ alkyl group). ${ }^{17}$ ) Formulae of the phosphines are illustrated in Scheme 2. The steric hindrance of phosphorinanes $(\mathbf{6 a - 6 g})$ is considered to be small compared to that of diisopropylphosphines $(\mathbf{7 a}-\mathbf{7 g})$ because of the alicyclic 
structure of the former. The reaction was carried out in the presence of 1,1,8,8-tetramethylhexamethylenediamine (TMHMDA) in tetraglyme (TGM) solvent under $\mathrm{CO} / \mathrm{H}_{2}(1 / 2)$ pressure of 500 bar at $220^{\circ} \mathrm{C}$. The amine may act as the stabilizing and promoting reagent for the catalytically active species. ${ }^{18)}$ The maximum rate of $\mathrm{EG}$ formation with phosphorinanes $(\mathbf{6 a - 6 g})$ and with diisopropylphosphines $(\mathbf{7 a - 7 g})$ are observed at the phosphine/ $\mathrm{Rh}$ molar ratio of 2 and 5 respectively, in the examination of the effect of addition ratio of the phosphines. A single IR band observed in the region of $1,960-1,950 \mathrm{~cm}^{-1}$ for the reaction solutions suggests the formation of $\mathrm{a}\left[\mathrm{Rh}(\mathrm{CO})_{3} \mathrm{~L}\right]_{2}$ ( $\mathrm{L}=$ phosphine) complex in every case.

Electronic parameters of the phosphine

The maximum rates of $\mathrm{EG}$ and $\mathrm{MeOH}$ formation under reaction conditions (phosphine $/ \mathrm{Rh}=2$ : $\mathbf{6 a - 6 g}$; phosphine $/ \mathrm{Rh}=5: \mathbf{7 a}-\mathbf{7 g}$ ) are summarized in Table 3. Linear relationships are found

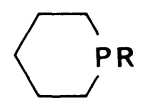

$$
\operatorname{Pr}_{2} \text { PR }
$$

\begin{tabular}{llll} 
& $\mathrm{R}$ & \multicolumn{2}{c}{} \\
$6 \mathrm{a}$ & $\mathrm{Me}$ & $7 \mathrm{a}$ & $\mathrm{Me}$ \\
$6 \mathrm{~b}$ & $\mathrm{Et}$ & $7 \mathrm{~b}$ & $\mathrm{Bu}^{\mathrm{n}}$ \\
$6 \mathrm{c}$ & $\mathrm{Bu}^{\mathrm{n}}$ & $7 \mathrm{c}$ & $\mathrm{Et}$ \\
$6 \mathrm{~d}$ & $\mathrm{C}-\mathrm{C}_{6} \mathrm{H}_{11}$ & $7 \mathrm{~d}$ & $\mathrm{C}-\mathrm{C}_{6} \mathrm{H}_{11}$ \\
$6 \mathrm{e}$ & $\mathrm{Pr}^{\mathrm{i}}$ & $7 \mathrm{e}$ & $\mathrm{Bu}^{\mathrm{s}}$ \\
$6 \mathrm{f}$ & $\mathrm{Bu}^{\mathrm{s}}$ & $7 f$ & $\mathrm{Pr}^{\mathrm{i}}$ \\
$6 \mathrm{~g}$ & $\mathrm{Bu}^{\mathrm{t}}$ & $7 \mathrm{~g}$ & $\mathrm{Bu}^{\mathrm{t}}$
\end{tabular}

Scheme 2 Formulae of the Phosphines between the relative rates to EG and Taft's substitution constants of the alkyl substituents in phosphorinane (not including $6 \mathbf{g}$ ) or in diisopropylphosphine. These are expressed in Eq. 1 (phosphorinanes; correlation coefficient, - 0.987) and Eq. 2 (diisopropylphosphines; correlation coefficient, - 0.952) ( $r_{0}$ : rate to EG with phosphine where alkyl substituent is a methyl group).

$$
\begin{aligned}
& \log \left(r / r_{0}\right)=-3.17 \sigma^{*} \\
& \log \left(r / r_{0}\right)=-0.72 \sigma^{*}
\end{aligned}
$$

The electron-donating effect of the alkyl substituent facilitates the formation of EG. The rate of $\mathrm{EG}$ formation with $\mathbf{6 g}$ is lower than that estimated from Eq. 1. This is thought to be due to the large steric hindrance of the $\mathrm{Bu}^{\mathrm{t}}$ group to the coordination of the ligand to the rhodium metal. The value of $\rho$ with respect to the phosphorinanes is 4.4 times greater than that with respect to the diisopropylphosphines. The large contribution of the electronic effect of the alkyl substituent is clarified for alkyl-substituted phosphorinanes. The reason is presented below.

\section{Steric parameters of the phosphine}

The cone angle of the phosphine has been chosen as a measure of the steric parameter of the ligand. The cone angle has also been shown to be correlated with the value of the ${ }^{31} \mathrm{P}-\mathrm{NMR}$ chemical shift for the phosphine. ${ }^{19)}$ If the relation between the two parameters is expressed by a simple equation, the chemical shift can be used as a measure of the steric parameter of the phosphine ligand.

A change in the chemical shift, $\Delta^{20)}$, which is defined in Eq. 3, has been shown to decrease with an increase in the cone angle of the phosphine. ${ }^{19)}$

$$
\Delta=\delta \text { (complex) }-\delta \text { (free) }
$$

\begin{tabular}{|c|c|c|c|c|c|c|c|}
\hline \multirow[b]{2}{*}{ No. } & \multirow{2}{*}{$\underset{\left({ }^{\circ}\right)}{\text { Congle }}$} & \multicolumn{2}{|c|}{${ }^{31} \mathrm{P}-\mathrm{NMR}$ chemical shift (ppm) } & \multirow{2}{*}{$\begin{array}{c}\Delta \\
(\mathrm{ppm})\end{array}$} & \multirow{2}{*}{$\begin{array}{l}\nu(\mathrm{CO})^{\mathrm{c})} \\
\left(\mathrm{cm}^{-1}\right)\end{array}$} & \multicolumn{2}{|c|}{ Turnover number $\left(\mathrm{hr}^{-1}\right)$} \\
\hline & & $\delta($ free $)$ & $\left.\delta(\text { complex })^{b}\right)$ & & & EG & $\mathrm{MeOH}$ \\
\hline $6 a$ & 122 & -52.20 & -1.64 & 50.59 & 1965.0 & 7.38 & 50.73 \\
\hline $6 \mathrm{~b}$ & 127 & -37.00 & 11.19 & 48.19 & 1962.8 & 13.84 & 75.13 \\
\hline $6 c$ & 127 & -40.99 & 8.89 & 49.88 & 1957.3 & 20.00 & 71.23 \\
\hline $6 \mathrm{~d}$ & 139 & -29.64 & 17.73 & 47.37 & 1952.4 & 25.42 & 61.36 \\
\hline $6 e$ & 136 & -23.96 & 23.26 & 47.22 & 1953.7 & 29.78 & 78.12 \\
\hline $6 f$ & 136 & -28.03 & 21.61 & 49.64 & 1952.6 & 31.61 & 67.85 \\
\hline $6 \mathrm{~g}$ & 143 & -12.63 & 27.74 & 40.37 & 1951.5 & 32.95 & 31.64 \\
\hline $7 \mathrm{a}$ & 146 & -8.71 & 35.41 & 44.12 & 1953.0 & 14.39 & 41.00 \\
\hline $7 b$ & 151 & 4.68 & 44.62 & 39.94 & 1949.7 & 18.02 & 34.25 \\
\hline $7 \mathrm{c}$ & 151 & 9.93 & 45.56 & 35.63 & 1950.8 & 18.71 & 33.70 \\
\hline $7 d$ & 163 & 18.55 & 45.52 & 26.98 & 1946.0 & 19.72 & 27.74 \\
\hline $7 e$ & 160 & 18.31 & 51.29 & 32.98 & 1946.5 & 20.43 & 35.21 \\
\hline $7 f$ & 160 & 21.65 & 49.51 & 27.86 & 1947.2 & 22.38 & 33.53 \\
\hline $7 \mathrm{~g}$ & 167 & 34.97 & 58.35 & 23.38 & 1945.4 & 23.89 & 27.79 \\
\hline
\end{tabular}

Thus, the steric hindrance of bulky substituents of the phosphine to its coordination to the

Table 3 Spectral Data and Promoting Effects of Phosphine (L) ${ }^{\text {a) }}$

a) Reaction conditions : $\mathrm{Rh}(\mathrm{acac})(\mathrm{CO})_{2}, 0.1$ mmole; TMHMDA, 3 mmole; L/Rh=2 (L:6a-6g); 5 (L : 7a-7g); TGM, 5 ml; $\mathrm{CO} / \mathrm{H}_{2}(1 / 2) 510-500$ bar; $220^{\circ} \mathrm{C} ; 1 \mathrm{hr}$. Spectral measurement conditions : NMR $\left(\mathrm{CDCl}_{3} ;\right.$ standard : $\left.\mathrm{H}_{3} \mathrm{PO}_{4}\right) ; \mathrm{IR}\left(\mathrm{CH}_{2} \mathrm{Cl}_{2}\right)$.

b) $\mathrm{Rh}_{4}(\mathrm{CO})_{11} \mathrm{~L}$ (axial phosphine).

c) $\mathrm{RhCl}(\mathrm{CO}) \mathrm{L}_{2}$. 
rhodium metal decreases with an increase in the value of $\Delta$. We have chosen $\mathrm{Rh}_{4}(\mathrm{CO})_{11} \mathrm{~L}$ as the rhodium complex for determining the $\Delta$ value. This choice is motivated by the following circumstances:

(a) Since the formation of $\left[\mathrm{Rh}(\mathrm{CO})_{3} \mathrm{~L}\right]_{2}$ is identified in the IR spectra of the reaction solutions, the active species is suggested to be a rhodium complex with a phosphine ligand ${ }^{6), 7)}$;

(b) The complex $\left[\mathrm{Rh}(\mathrm{CO})_{3} \mathrm{~L}\right]_{2}$ is unstable for spectroscopic measurements, but the stable complex, $\mathrm{Rh}_{4}(\mathrm{CO})_{11} \mathrm{~L}$, is easily prepared, and the value of the chemical shift varies to a great extent depending on the structure of the phosphine ligand.

The cone angles ${ }^{\dagger 1)}$ of the phosphines, the values of $\delta$ (free), $\delta$ (complex), and $\Delta$ are shown in Table 3 with the $\nu(\mathrm{CO})$ value for the $\operatorname{RhCl}(\mathrm{CO}) \mathrm{L}_{2}$ complex. Since a linear relationship is found between the cone angle and $\delta$ (free) value with a correlation coefficient of 0.987 , the $\delta$ (free) can be adopted as a measure of the steric parameter of the phosphine ligand. The relation between $\Delta$ and $\delta$ (free) is shown in Fig. 1. The fact that the value of $\Delta$ for the complexes with phosphorinanes (not including 6g) are almost constant and independent of $\delta$ (free) indicates that the steric effect is not important for $\mathbf{6 a - 6 f}$ because of the less crowded

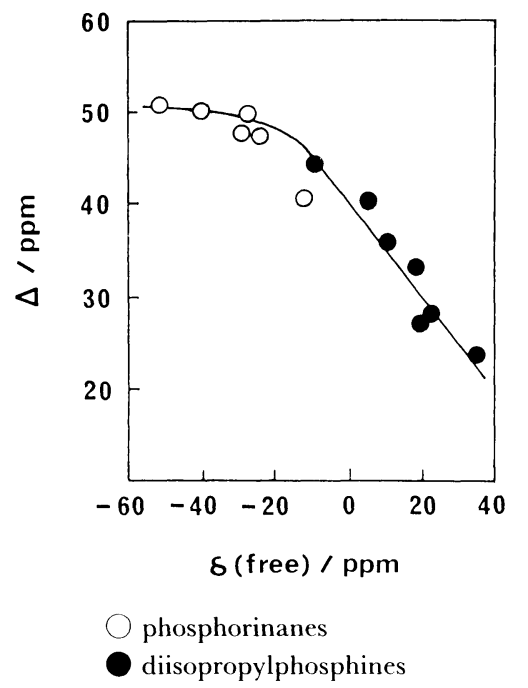

Fig. 1 Relation between $\Delta$ and $\delta$ (Free)

${ }^{\dagger 1}$ Cone angle $\theta$ for an unsymmetrical ligand can be estimated by the following equation given by Tolman. ${ }^{19}$

$$
\theta=\frac{2}{3} \sum_{i=1}^{3}\left(\frac{\theta_{i}}{2}\right)
$$

where $\theta_{i}$ is the half-angle. Half-angles for alkyl substituents $R$ are calculated from the equation using $\theta$ listed in Appendix of reference 19. The half-angle for phosphorinane $\left(\theta_{i}=62^{\circ}\right)$, which was not reported previously, has been measured by Tolman's method ${ }^{19)}$ using CPK molecular models. alicyclic structure of the phosphines. The small $\Delta$ value of $\mathrm{Rh}_{4}(\mathrm{CO})_{11} \mathrm{~L}(\mathrm{~L}=\mathbf{6 g})$ as compared to the values of the complexes with the other phosphorinanes is ascribed to the large steric hindrance of the $\mathrm{Bu}^{\mathrm{t}}$ group of $\mathbf{6 g}$.

A linear relationship is found between $\Delta$ value and $\delta$ (free) for diisopropylphosphines as shown in Fig. 1. This suggests that coordination ability of diisopropylphosphines $\mathbf{7 a}-\mathbf{7 g}$ on coordination decrease with an increase in the bulkiness of the phosphines. As mentioned above, the $\rho$ value of Eq. 2 is much lower than that of Eq. 1. This indicates that the steric effects diminish the electronic effects in the EG formation.

\section{Selectivity to EG}

The value of $\nu(\mathrm{CO})$ for the $\mathrm{RhCl}(\mathrm{CO}) \mathrm{L}_{2}$ complex is known to be one of the electronic parameters for the phosphine. ${ }^{21)}$ This is a useful measure of the electronic effect when the sum of the substitution constants for the substituents of the phosphine cannot be obtained easily, e.g., in the case of phosphorinanes. The selectivity to EG, that is defined in $[\mathrm{EG}(\mathrm{mol})] /[\mathrm{EG}(\mathrm{mol})+\mathrm{MeOH}$ (mol)], with phosphine (not including 6g) correlates well with the value of $\nu(\mathrm{CO})$ for the $\mathrm{RhCl}(\mathrm{CO}) \mathrm{L}_{2}$ complexes, as shown in Fig. 2. It suggests that the selectivity increases with an increase in the electron-donating ability of the phosphine ligand. The electronic effect is considered to predominate over the steric effect of the phosphine in determining the selectivity because of the linear relationship between selectivity and $\nu(\mathrm{CO})$ value. In the $\mathrm{Rh}$ phosphine-amine system, $\mathrm{MeOH}$ is proposed to be formed mainly via methoxide rhodium intermediate (Scheme 1). ${ }^{22)}$ Just as the mode of the addition reaction of the formaldehyde intermediate to the $\mathrm{Rh}-\mathrm{H}$ bond influences the



Fig. 2 Relation between EG Selectivity and $\nu(\mathrm{CO})$ for $\mathrm{RhCl}(\mathrm{CO}) \mathrm{L}_{2}$ 
selectivity to EG, the electron-donating effect of the substituent on the phosphorus atom may affect the mode of the addition reaction.

\subsection{A Synergistic Effect of Phosphine and Acid}

The direct conversion of synthesis gas into EG catalyzed by the Rh-phosphine system is preferably carried out in basic media. ${ }^{8)}$ We have conducted the rhodium catalysis in the presence of organic acids, especially carboxylic acids. ${ }^{23)}$

The Rh-tricyclohexylphosphine (TCP) system

Table 4 shows the effect of TCP concentration on the rate of $\mathrm{EG}$ and $\mathrm{MeOH}$ formation catalyzed by $\mathrm{Rh}_{4}(\mathrm{CO})_{12}$ in $\mathrm{DMI}$ or in TGM solvent. In the absence of TCP, the rate to EG of $9.63 \mathrm{hr}^{-1}$ was more than twice the rate to $\mathrm{MeOH}$ of $4.12 \mathrm{hr}^{-1}$ in DMI. The rate to EG increases barely, and the rate to $\mathrm{MeOH}$ increases remarkably with an increase in the TCP concentration. Increasing the concentration of TCP diminishes the selectivity to EG, while the rate of carbon monoxide hydrogenation (sum of the rates to $\mathrm{EG}$ and $\mathrm{MeOH}$ ) reaches its maximum value at a molar ratio $\mathrm{TCP} / \mathrm{Rh}=2$ in DMI solvent. The IR studies show the formation of $\left[\mathrm{Rh}(\mathrm{CO})_{3}(\mathrm{TCP})\right]_{2}(\mathbf{8})$ in the resultant solution. On the other hand, no reaction occurs without TCP in TGM solution because of the decomposition of the catalyst to rhodium metal. The rates to $\mathrm{EG}$ and $\mathrm{MeOH}$ increase with an increase in the concentration of TCP, and the rate to $\mathrm{EG}$ reaches a maximum value of $7.28 \mathrm{hr}^{-1}$ at $\mathrm{TCP} / \mathrm{Rh}=20$.

\section{Effect of acid additives}

Table 5 shows the effect of 3 -fluorobenzoic acid

Table 4 Catalytic Activities of the Rh-TCP System ${ }^{\text {a) }}$

\begin{tabular}{c|ccc}
\hline \multirow{2}{*}{ Solvent } & $\begin{array}{c}\text { TCP/Rh } \\
\text { (mole/mole })\end{array}$ & \multicolumn{2}{c}{ Turnover number $\left(\mathrm{hr}^{-1}\right)$} \\
& - & 9.63 & $\mathrm{MeOH}$ \\
\hline \multirow{2}{*}{ DMI } & 1 & 10.68 & 4.12 \\
& 2 & 10.14 & 25.68 \\
& 4 & 6.12 & 20.79 \\
TGM & 2 & 0.90 & 17.36 \\
& 4 & 2.43 & 24.44 \\
& 10 & 4.92 & 18.40 \\
& 20 & 7.28 & 13.05 \\
\hline
\end{tabular}

a) $[\mathrm{Rh}]=0.013 \mathrm{M}\left[\mathrm{Rh}_{4}(\mathrm{CO})_{12}\right.$ was used]; solvent, $7.5 \mathrm{~m} /$; $\mathrm{CO} / \mathrm{H}_{2}(\mathrm{l} / \mathrm{l}), 550-500 \mathrm{bar} ; 220^{\circ} \mathrm{C} ; 2 \mathrm{hr}$.

Table 5 Effects of 3-Fluorobenzoic Acid (FBA) and TCP ${ }^{a}$

\begin{tabular}{|c|c|c|c|c|}
\hline $\begin{array}{c}\mathrm{TCP} / \mathrm{Rh} \\
\text { (mole/mole) }\end{array}$ & $\begin{array}{c}\mathrm{FBA} / \mathrm{Rh} \\
(\mathrm{mole} / \mathrm{mole})\end{array}$ & Solvent & $\begin{array}{c}\text { Turnover } \\
\text { EG }\end{array}$ & $\begin{array}{c}\text { number }\left(\mathrm{hr}^{-1}\right) \\
\mathrm{MeOH}\end{array}$ \\
\hline 2 & 1 & \multirow{7}{*}{ DMI } & 9.72 & 25.48 \\
\hline 2 & 2 & & 11.12 & 24.67 \\
\hline 2 & 10 & & 14.27 & 23.41 \\
\hline 2 & 20 & & 15.87 & 18.11 \\
\hline 2 & 50 & & 18.31 & 10.59 \\
\hline 1 & 50 & & 12.60 & 12.52 \\
\hline 3 & 50 & & 16.58 & 27.16 \\
\hline 2 & 1 & \multirow{2}{*}{ TGM } & 2.56 & 20.50 \\
\hline 2 & 10 & & 4.65 & 21.45 \\
\hline
\end{tabular}

a) Reaction conditions as in Table 4 .
(FBA) and TCP concentrations in the formations of EG and MeOH in DMI or in TGM. The following generalizations were deduced:

(1) The rate and selectivity of EG formation increase with an increase in the FBA concentration; (2) no esters originating from FBA are found in the products; (3) the maximum rate of EG formation is observed at TCP/Rh $=2$; (4) the band at $1,946 \mathrm{~cm}^{-1}$ is observed in all reaction solutions shown in Table 5, and this absorption does not change in air at room temperature for as long as few weeks.

A linear correlation is found between the selectivity to EG and the ratio of $\mathrm{FBA} / \mathrm{Rh}$ with a correlation coefficient of 0.998 . It suggests that the acid may affect the mode of addition of the formaldehyde intermediate to the $\mathrm{Rh}-\mathrm{H}$ bond to favorably form the hydroxymethylrhodium intermediate (refer to Scheme 1).

We have examined the promoting effects of various acids on the hydrogenation of carbon monoxide with the Rh-TCP system, and the results are summarized in Table 6. The promoting effects of carboxylic acids and pentafluorophenol are found in DMI solvent. The rate and selectivity of EG formation in the phosphoric acid system are comparable to those in the FBA system, but no reactions occur in the hydroiodic acid system, which yields $\left[\mathrm{RhI}_{2}(\mathrm{CO})_{2}\right]^{-}(2,051$ and $\left.1,980 \mathrm{~cm}^{-1}\right){ }^{24)}$

Identification and catalytic activity of the recovered complex

An air-stable yellow complex is isolated in $70 \%$ yield by allowing the resultant solution of DMI or of TGM with the Rh-TCP-FBA system to stand overnight at $0^{\circ} \mathrm{C}$. This compound is identified as $\mathrm{Rh}\left(3-\mathrm{F}-\mathrm{C}_{6} \mathrm{H}_{4} \mathrm{CO}_{2}\right)(\mathrm{CO})(\mathrm{TCP})_{2}(9)$, which is well known as Vaska complex of the type $\mathrm{RhX}(\mathrm{CO}) \mathrm{L}_{2}$ ( $\mathrm{X}=$ anionic ligand; $\mathrm{L}=$ phosphine). Analyses of the complex are:

IR $\left(\mathrm{KBr} ; \mathrm{cm}^{-1}\right): \quad 1,945(\mathrm{CO}), 1,630\left(\mathrm{CO}_{2}\right), 760$

Table 6 Effects of Various Acids on the Rh-TCP System $^{\text {a) }}$

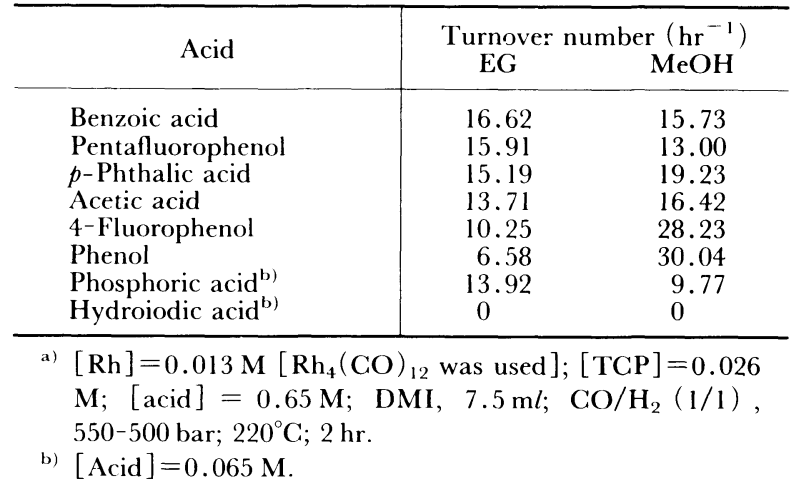


$\left(3-\mathrm{F}-\mathrm{C}_{6} \mathrm{H}_{4}\right)$;

NMR (CDCl 3 ; ppm): 1-2.5 (cyclohexyl; 66H), $7-8\left(\mathrm{C}_{6} \mathrm{H}_{4} ; 4 \mathrm{H}\right)$;

ESCA (eV): 307.8 [cf. $\mathrm{Rh}_{4}(\mathrm{CO})_{12}, 306.2$; RhCl$\left.(\mathrm{CO})\left(\mathrm{PPh}_{3}\right)_{2}, 307.6\right]$

FD-MS $\left(\mathrm{M}^{+}\right): 830$ (calcd. for $\mathrm{C}_{44} \mathrm{H}_{70} \mathrm{FO}_{3} \mathrm{P}_{2^{-}}$ $\mathrm{Rh}, 830$ );

Microanal. (\%), found: C, 63.10; H, 7.96; F, 1.93; P, 7.01; Rh, 12.50; calcd: C, 63.60; H, 8.49; F, 2.29; P, 7.46; $\mathrm{Rh}, 12.40$.

In the next step, we have examined catalytic activities of $\mathrm{RhX}(\mathrm{CO}) \mathrm{L}_{2}$, and the results are shown in Table 7. ${ }^{25)}$ Complex $\mathrm{RhX}(\mathrm{CO}) \mathrm{L}_{2}$ gives an excellent yield of EG compared to the Rh-HXL system (Table 6). Complexes of the type, $\mathrm{RhX}(\mathrm{CO}) \mathrm{L}_{2}$, have been shown to be readily obtainable in high yields ${ }^{26}$ ) by the reaction of $\mathrm{Rh}_{4}(\mathrm{CO})_{12}, \mathrm{HX}$, and $\mathrm{L}$. We have found that $\mathrm{RhX}(\mathrm{CO}) \mathrm{L}_{2}$ is reduced to give $\mathrm{Rh}(\mathrm{CO})_{4^{-}}$, under atmospheric pressure of synthesis gas and in an aprotic solvent, such as hexamethylphosphorictriamide (HMPA), via $\mathrm{HRh}(\mathrm{CO})_{2} \mathrm{~L}_{2}$ and $\mathrm{Rh}(\mathrm{CO})_{3} \mathrm{~L}^{-}$ as intermediates. ${ }^{25), 26)}$ The reduction rates are shown in Table 7. A linear correlation with a slope of 0.997 and a correlation coefficient of 0.979 is found between relative rate for $\mathrm{EG}$ formation catalyzed by $\mathrm{RhX}(\mathrm{CO}) \mathrm{L}_{2}$ [based on the rate with $\left.\mathrm{Rh}\left(\mathrm{C}_{6} \mathrm{H}_{5} \mathrm{CO}_{2}\right)(\mathrm{CO})(\mathrm{TCP})_{2}\right]$ and relative rate of the reduction of $\mathrm{RhX}(\mathrm{CO}) \mathrm{L}_{2}$ to $\mathrm{Rh}(\mathrm{CO})_{4}^{-}$. This suggests that the rhodium hydride species, which may be formed by reduction of $\mathrm{RhX}(\mathrm{CO}) \mathrm{L}_{2}$ under atmospheric pressure of synthesis gas, play an important role in EG formation.

Catalytic active species

The reaction of $\left[\mathrm{Rh}(\mathrm{CO})_{3}(\mathrm{TCP})\right]_{2}(\mathbf{8})$ with an equivalent of bis(triphenylphosphine) iminium acetate (PPNOAc) in the presence of an equivalent of TCP was found to form such complexes as $\mathrm{Rh}(\mathrm{OAc})(\mathrm{CO})(\mathrm{TCP})_{2}$ and $[\mathrm{PPN}]\left[\mathrm{Rh}(\mathrm{CO})_{3}(\mathrm{TCP})\right]$, according to Eq. $4 .{ }^{26)}$

$$
\begin{aligned}
8 & + \text { PPNOAc }+ \text { TCP } \\
& \longrightarrow \text { Rh }(\mathrm{OAc})(\mathrm{CO})(\mathrm{TCP})_{2} \\
& +[\mathrm{PPN}]\left[\mathrm{Rh}(\mathrm{CO})_{3}(\mathrm{TCP})\right]+2 \mathrm{CO}
\end{aligned}
$$

Thus, $\operatorname{RhX}(\mathrm{CO})(\mathrm{TCP})_{2}$, unstable $\mathrm{HRh}(\mathrm{CO})_{3}$ (TCP) (10) and $\mathrm{HRh}(\mathrm{CO})_{2}(\mathrm{TCP})_{2}$ (11) may be obtained from 8, HX, and TCP according to Eqs. 5 and 6.

$$
\begin{gathered}
8+\mathrm{HX}+\mathrm{TCP} \longrightarrow \mathrm{RhX}(\mathrm{CO})(\mathrm{TCP})_{2} \\
+\mathrm{HRh}(\mathrm{CO})_{3}(\mathrm{TCP})+2 \mathrm{CO} \\
\mathrm{HRh}(\mathrm{CO})_{3}(\mathrm{TCP})+\mathrm{TCP} \\
\longrightarrow \mathrm{HRh}(\mathrm{CO})_{2}(\mathrm{TCP})_{2}+\mathrm{CO}
\end{gathered}
$$

Synergistic effects of various additives on the catalytic activities using $\mathrm{Rh}\left(\mathrm{C}_{6} \mathrm{H}_{5} \mathrm{CO}_{2}\right)(\mathrm{CO})$ $(\mathrm{TCP})_{2}(\mathbf{1 2})$ as the catalyst precursor in TGM are shown in Table 8, in which comparative data with the Rh-TCP system are also shown. The rate and selectivity to EG increase on addition of excess benzoic acid. The acid facilitates the formation of 10 (Eq. 5) and 11 (Eq. 6). This nucleophilic reaction (5) would also be enhanced by addition of alkali salts etc. It is noted that addition of an equimolar amount of a salt, such as a cesium or a PPN salt, increases the rate and selectivity of EG

Table 8 Catalytic Activities of $\mathrm{Rh}\left(\mathrm{PhCO}_{2}\right)(\mathrm{CO})(\mathrm{TCP})_{2}$ with or without Additives ${ }^{\text {a) }}$

\begin{tabular}{c|cc}
\hline \multicolumn{1}{c|}{ Salt } & EG & $\begin{array}{c}\text { Turnover number }\left(\mathrm{hr}^{-1}\right) \\
\mathrm{MeOH}\end{array}$ \\
\hline- b) & 0.90 & 17.36 \\
- & 2.81 & 35.18 \\
-c) $^{\mathrm{CsI}}$ & 5.73 & 24.45 \\
CsBr & 13.88 & 18.20 \\
CiGl & 13.98 & 18.23 \\
CsF & 13.88 & 14.94 \\
PPNOAc & 12.52 & 12.65 \\
\hline
\end{tabular}

\begin{tabular}{|c|c|c|c|}
\hline $\mathrm{X}^{\mathrm{c})}$ & EG & $\mathrm{MeOH}$ & $\begin{array}{l}\text { Reduction } \\
\text { rate }\left(10^{3} \times \min ^{-1}\right)\end{array}$ \\
\hline $\begin{array}{l}\mathrm{PhCO}_{2} \\
4-\mathrm{HO}_{2} \mathrm{C}-\mathrm{C}_{6} \mathrm{H}_{4} \mathrm{CO}_{2} \\
3-\mathrm{HO}_{2} \mathrm{C}-\mathrm{C}_{6} \mathrm{H}_{4} \mathrm{CO}_{2} \\
3-\mathrm{F}-\mathrm{C}_{6} \mathrm{H}_{4} \mathrm{CO}_{2} \\
4-\mathrm{O}_{2} \mathrm{~N}^{-} \mathrm{C}_{6} \mathrm{H}_{4} \mathrm{CO}_{2} \\
3-\mathrm{F}-\mathrm{C}_{6} \mathrm{H}_{4} \mathrm{CO}_{2}{ }^{\mathrm{d})} \\
\mathrm{C}_{6} \mathrm{~F}_{5} \mathrm{O} \\
4-\mathrm{Me}^{-\mathrm{C}_{6}} \mathrm{H}_{4} \mathrm{SO}_{3} \\
\quad \\
\left.\quad-{ }_{-}^{\mathrm{d})}, \mathrm{e}\right)\end{array}$ & $\begin{array}{r}24.60 \\
20.93 \\
19.23 \\
18.30 \\
17.16 \\
14.12 \\
11.49 \\
0.24 \\
7.09 \\
8.81\end{array}$ & $\begin{array}{r}20.80 \\
28.36 \\
28.61 \\
30.65 \\
30.01 \\
42.40 \\
37.53 \\
0.45 \\
43.41 \\
30.42\end{array}$ & $\begin{array}{r}17.16 \\
11.73 \\
12.40 \\
12.73 \\
9.87 \\
8.00 \\
6.80 \\
0 \\
-\end{array}$ \\
\hline
\end{tabular}

a) $[\mathrm{Rh}]=0.02 \mathrm{M}$; $[\mathrm{Cs}]$ or $[\mathrm{PPN}]=0.02 \mathrm{M}$; TGM, $5 \mathrm{ml}$; $\mathrm{CO} / \mathrm{H}_{2}(1 / 1), 550-500$ bar; $220^{\circ} \mathrm{C} 2 \mathrm{hr}$.

b) Refer to Table 4 .

c) $\left[\mathrm{PhCO}_{2} \mathrm{H}\right]=0.2 \mathrm{M}$ was employed.

d) $\mathrm{Bis}$ (triphenylphosphine) iminium acetate.

Table 7 Catalytic Activities of $\mathrm{RhX}(\mathrm{CO}) \mathrm{L}_{2}{ }^{a}$ a) and Initial Reduction Rates of the Complexes under Synthesis Gas ${ }^{\mathrm{b})}$

a) $[\mathrm{Rh}]=0.02 \mathrm{M}$; solvent, $5 \mathrm{ml} ; \mathrm{CO} / \mathrm{H}_{2}(1 / 1), 540-510 \mathrm{bar} ; 220^{\circ} \mathrm{C} ; 1 \mathrm{hr}$

b) $[\mathrm{Rh}]=0.02 \mathrm{M}$; solvent (HMPA), $5 \mathrm{ml} ; \mathrm{CO} / \mathrm{H}_{2}(1 / 1), 1 \mathrm{~atm} . ; 20^{\circ} \mathrm{C}$.

c) $\mathrm{L}=$ tricyclohexylphosphine.

d) $\mathrm{L}=$ triisopropylphosphine.

c) $\mathrm{Rh}_{4}(\mathrm{CO})_{12}$ and $\mathrm{L}$ were employed $(\mathrm{L}: \mathrm{Rh}=2: 1)$ instead of $\mathrm{RhX}(\mathrm{CO}) \mathrm{L}_{2}$. 
formation.

Infrared spectra of the reaction solutions containing Rh-TCP, 12, and 12-CsI were obtained under 280 bar of synthesis gas at room temperature. Since a single band at $1,955 \mathrm{~cm}^{-1}$ is observed, rhodium in the Rh-TCP system exists mainly as 8. In the reaction solution with 12 , bands at 2,041 , 1,972, and $1,944 \mathrm{~cm}^{-1}$, which are assigned to 11 , and one at $1,955 \mathrm{~cm}^{-1}(\mathbf{8})$ are observed. In the reaction solution with 12 and an equimolar amount of CsI, the concentration of $\mathbf{1 1}$ increases remarkably. The catalytic activity correlates well with the concentration of 11 . The formation of an analogous rhodium hydride complex $\mathrm{HRh}(\mathrm{CO})_{2}$ $\left(\mathrm{PPh}_{3}\right)_{2}$ has been found in the reduction products of $\mathrm{Rh}\left(3-\mathrm{F}-\mathrm{C}_{6} \mathrm{H}_{4} \mathrm{CO}_{2}\right)(\mathrm{CO})\left(\mathrm{PPh}_{3}\right)_{2}$ under atmospheric pressure of synthesis gas. ${ }^{26)}$ By depressurization of synthesis gas, the starting complex is recovered from the resultant solutions of $\mathrm{RhX}$ $(\mathrm{CO}) \mathrm{L}_{2}$ with or without an additive.

A plausible reaction pathway of the rhodium complex is shown in Scheme 3. The initially charged $\mathrm{RhX}(\mathrm{CO}) \mathrm{L}_{2}$ is reduced to form $\mathrm{HRh}$ $(\mathrm{CO})_{2} \mathrm{~L}_{2}$ and $\mathrm{HRh}(\mathrm{CO})_{3} \mathrm{~L}$. The former rhodium hydride species is considered to be catalytically active because of the maximum rate of EG formation at $\mathrm{L} / \mathrm{Rh}=2$ (Table 5). Complex $\mathrm{HRh}(\mathrm{CO})_{3} \mathrm{~L}$ may not only be converted into $\mathrm{HRh}(\mathrm{CO})_{4}$ by the ligand exchange reaction, but also into $\left[\mathrm{Rh}(\mathrm{CO})_{3} \mathrm{~L}\right]_{2}$ by its dimerization with the

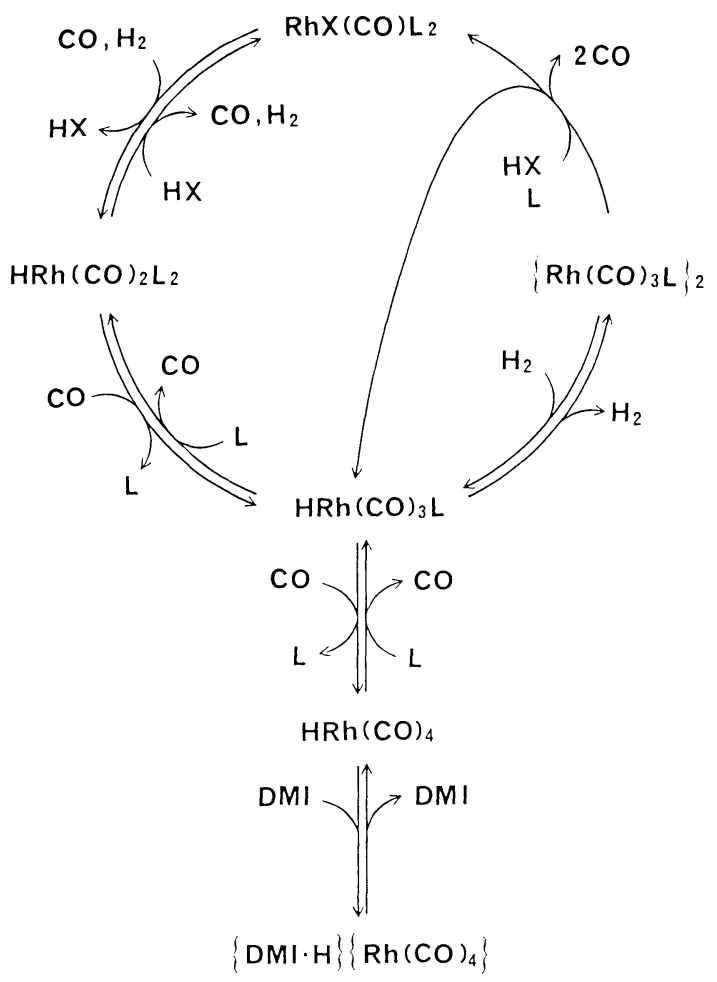

Scheme 3 Proposed Reaction Pathway of $\operatorname{RhX}(\mathrm{CO}) \mathrm{L}_{2}$ liberation of $\mathrm{H}_{2}$. Equilibria between $\left[\mathrm{Rh}(\mathrm{CO})_{3} \mathrm{~L}\right]_{2}$ and $\operatorname{HRh}(\mathrm{CO})_{m} \mathrm{~L}_{n}(1 \leq m \leq 4 ; m+n=4)$ are also proposed in the Rh-L system. ${ }^{18)}$ The anionic ligand $\mathrm{X}$ may be separated as $\mathrm{HX}$ under these conditions. The acid reacts with $\left[\mathrm{Rh}(\mathrm{CO})_{3} \mathrm{~L}\right]_{2}$ and $\mathrm{L}$ to form $\mathrm{RhX}(\mathrm{CO}) \mathrm{L}_{2}$ and $\mathrm{HRh}(\mathrm{CO})_{3} \mathrm{~L}$ as is indicated in Eq. 5. This reaction is irreversible, and it should be followed by reversible ligand exchange reaction (6), leading to the formation of plausible catalytically active species $\mathrm{HRh}(\mathrm{CO})_{2} \mathrm{~L}_{2}$. Acknowledgement

This work is a part of " $\mathrm{C}_{1}$ Chemistry Project", a National Research and Development Program of Agency of Industrial Science and Technology, Ministry of International Trade and Industry (M.I.T.I.), Japan. The author thanks the researchers of Central Research Laboratory, Mitsubishi Petrochemical Co. and research fellows of the "Ethylene Glycol Research Group" of the Project for their collaboration and discussions.

\section{References}

1) Dombek, B. D., Adv. Catal., 32, 325 (1983) and references therein.

2) US 2,534,018 (1950).

3) Keim, W., Berger, M., Schlupp, J., J. Catal., 61, 359 (1980).

4) US $3,833,634$ (1974).

5) Watanabe, E., Hara, Y., Wada, K., Onoda, T., Chem. Lett., 285 (1986).

6) Tanaka, H., Hara, Y., Watanabe, E., Wada, K., Onoda, T., J. Organomet. Chem., 312, C71 (1986).

7) Tamura, M., Ishino, M., Deguchi, T., Nakamura, S., J. Organomet. Chem., 312, C75 (1986).

8) Japan Kokai 60-149537 (1985).

9) Tomotake, Y., Matsuzaki, T., Murayama, K., Watanabe, E., Wada, K., Onoda, T., J. Organomet. Chem., 320, 239 (1987).

10) Ohgomori, Y., Mori, S., Yoshida, S., Watanabe, Y., Chem. Lett., 1935 (1986).

11) Ohgomori, Y., Mori, S., Yoshida, S., Watanabe, Y., J. Mol. Catal., 40, 223 (1987).

12) Chini, P., Longoni, G., Albano, V. G., Adv. Organomet. Chem., 14, 285 (1976).

13) Fahey, D. R., J. Am. Chem. Soc., 103, 136 (1981).

14) Collman, J. P., Winter, S. R., J. Am, Chem. Soc., 95, 4089 (1973).

15) Watanabe, E., Murayama, K., Hara, Y., Kobayashi, Y., Wada, K., Onoda, T., J. Chem. Soc., Chem. Commun., 227 (1986).

16) Wender, I., Pino, P., "Organic Synthesis via Metal Carbonyls," John Wiley and Sons, Vol. 2, p. 136 (1977).

17) Ohgomori, Y., Yoshida, S., Watanabe, Y., J. Mol. Catal., 43, 249 (1987).

18) Watanabe, E., Hara, Y., Matsuzaki, T., Wada, K., Onoda, T., Shokubai, 28, 154 (1986); Watanabe, E., Hara, Y., Matsuzaki, T., Murayama, K., Wada, K., Onoda, T., 5th. International Symposium on Homogeneous Catalysis, preprint, p. 180 (1986).

19) Tolman, C. A., Chem. Rev., 77, 313 (1977).

20) Mann, B. E., Mesters, C., Shaw, B. L., J. Chem. Soc. (A), $1104(1971)$.

21) Vastag, S., Heil, B., Marko, L., J. Mol. Catal., 5, 189 (1979). 
22) Ohgomori, Y., Yoshida, S., Watanabe, Y., 4th. Symposium on $C_{1}$ Catalysis (Tokyo), preprint, 62 (1987).

23) Ohgomori, Y., Mori, S., Yoshida, S., Watanabe, Y., J. Mol. Catal., 43, 127 (1987).

24) Vallarino, L. M., Inorg. Chem., 4, 161 (1965).
25) Ohgomori, Y., Yoshida, S., Watanabe, Y., J. Chem. Soc., Chem. Commun., 829 (1987).

26) Ohgomori, Y., Yoshida, S., Watanabe, Y., J. Chem. Soc., Dalton Trans., 2969 (1987).

要 旨

\section{ロジウム触媒による合成ガスからのエチレングリコール直接合成}

大䈕 祐二

三菱油化(株)中央研究所, 300-03 茨城県稲敷郡阿見町中央 8-3-1

合成ガス変換反応によるエチレングリコール（EG）の合成 において使用されるロジウム触媒の活性向上, 安定性の向上を

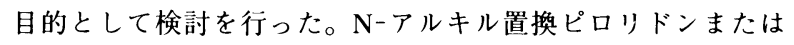
アルキル尿素誘導体を溶媒として使用する系では, 比較的温和 な条件の下に反応が進行し, 効率よく EG が生成することが 明らかとなった。Nーメチルピロリドン（NMP）と 1, 3-ジメチ ルイミダゾリドン (DMI) 溶媒系では, EG 選択率が大きく異 なる。両溶媒中での EG とメ夕ノールの中閒体の生成挙動を 詳細に調べた結果, 高い選択率を与える DMI 溶媒系では, $\mathrm{EG}$ 生成の中間体グリコールアルデヒドが安定化されているこ とが明らかとなった。

最近トリアルキルホスフィン（L）をプロモーターとするロ ジウム触媒が, 高い EG 生成活性を示すことが明らかにされ た。この系において, ホスフィンの電子論的効果, 立体化学的 効果が触媒活性に与える影響を調べた。その結果, ホスフィン のアルキル置換基の電子供与性の増大に伴って, EG 生成速度 が向上すること, またこの活性向上効果はホスフィンの立体的 な嵩高さが増加するにつれて抑制されることが明らかとなっ た. 六員環ホスフィンであるホスホリナン類は立体効果が非常 に小さく, 本系において最も有効な配位子群であることが明ら
かとなった。また EG はホスフィンの塩基性が高いほど選択 率良く生成することを明らかにした。

上述の触媒は, 反応後に不安定な $\left[\mathrm{Rh}(\mathrm{CO})_{3} \mathrm{~L}\right]_{2}$ 型錯体を与 える。そこで触媒活性の向上, 安定性の向上を目的として, 有 機酸 $(\mathrm{HX})$ の添加効果を検討したところ, カルボン酸やフェ ノール, リン酸が共存すると, EG 生成速度および選択率が向 上するのみならず，ロジウムは，空気や熱に安定で繰り返し使 用の容易な $\mathrm{RhX}(\mathrm{CO}) \mathrm{L}_{2}$ 型錯体として, ほぼ定量的に回収さ れることが明らかとなった。 $\mathrm{RhX}(\mathrm{CO}) \mathrm{L}_{2}$ 型錯体を触媒とし て使用すると, 更に高い EG 生成速度が得られる。更に HX の役割を調べ，活性種として $\mathrm{HRh}(\mathrm{CO})_{2} \mathrm{~L}_{2}$ を推定した。 $\mathrm{RhX}$ (CO) $\mathrm{L}_{2}$ は反応条件下，合成ガスによって容易に還元され $\mathrm{HRh}(\mathrm{CO})_{2} \mathrm{~L}_{2}$ と酸 $\mathrm{HX}$ を与える。このヒドリド種は $\mathrm{HRh}$ $(\mathrm{CO})_{3} \mathrm{~L}$ を経て，脱水素二量化により不活性な種 $\left[\mathrm{Rh}(\mathrm{CO})_{3} \mathrm{~L}\right]_{2}$ へ変換される。一方この錯体は $\mathrm{HX}$ および $\mathrm{L}$ との反応で $\mathrm{RhX}(\mathrm{CO}) \mathrm{L}_{2}$ と $\mathrm{HRh}(\mathrm{CO})_{3} \mathrm{~L}$ を与えるが, 後者は $\mathrm{L}$ にる配 位子置換反応によって, 速やかに $\mathrm{HRh}(\mathrm{CO})_{2} \mathrm{~L}_{2}$ に変換される。 このように酸は活性種を生成するための鍵となる反応にあずか るものと推定された。

\section{Keywords}

Carbon monoxide, Complex catalyst, Ethylene glycol, Homogeneous catalysis, Hydrogen, Hydrogenation 